\title{
Effect of Sodium on Nitrogen Fixation in Anabaena torulosa and Plectonema boryanum
}

\author{
By SHREE KUMAR APTE AND JOSEPH THOMAS* \\ Biology \& Agriculture Division, Bhabha Atomic Research Centre, Trombay, \\ Bombay 400 085, India
}

(Received 2 June 1983; revised 12 December 1983)

\begin{abstract}
The cyanobacterium Anabaena torulosa required sodium and molybdenum for nitrogenase activity and diazotrophic growth. Addition of sodium or molybdenum to cultures deficient in either element restored nitrogenase activity. Heterocyst differentiation was unaffected by sodium but molybdenum deficiency enhanced differentiation. The non-heterocystous cyanobacterium Plectonema boryanum 594 also required sodium for nitrogenase activity but synthesized presumptive nitrogenase component I and II proteins during sodium deficiency. The results show that in cyanobacteria nitrogenase is synthesized even in the absence of sodium but functions only in its presence.
\end{abstract}

\section{INTRODUCTION}

Sodium is an important nutritional requirement for cyanobacteria (Allen \& Arnon, 1955; Kratz \& Myers, 1955; Batterton \& Van Baalen, 1971). The amount needed is very low but the requirement is specific (see Wolk, 1973) and cannot be substituted by potassium, lithium or caesium. The biochemical basis of sodium nutrition is not clear. Sodium deficiency has been shown to increase the assimilation of nitrate in Anabaena cylindrica whereas the incorporation of ${ }^{15} \mathrm{~N}_{2}$ decreases (Brownell \& Nicholas, 1967). Recently sodium has been found to be essential for nitrogenase activity in cyanobacteria (Apte \& Thomas, 1980, 1983) although its mode of action remains to be established.

Molybdenum forms part of the iron-molybdenum cofactor (Shah \& Brill, 1977; Eady et al., 1980), a constituent of the MoFe protein or component I of nitrogenase (Eady \& Postgate, 1974), and there is evidence that it is the putative substrate binding site in functional nitrogenase (Nagatani \& Brill, 1974; Thorneley et al., 1980). Molybdenum has also been implicated in the regulation of nitrogenase synthesis, although its precise role has been a matter of controversy (Brill et al., 1974; Kennedy \& Postgate, 1977). Thus molybdenum is essential for the synthesis of both component I and II in Clostridium pasteurianum (Cardenas \& Mortenson, 1975) and of component I in Azotobacter vinelandii (Nagatani \& Brill, 1974), while in Klebsiella pneumoniae (Kahn et al., 1982), Anabaena cylindrica (Hallenbeck \& Benemann, 1980) and Plectonema boryanum (Nagatani \& Haselkorn, 1978) nitrogenase synthesis is independent of molybdenum.

We have examined the sodium requirement of Anabaena torulosa, a heterocystous and aerobic diazotroph, and of Plectonema boryanum, a non-heterocystous and microaerophilic diazotroph. In order to gain information on the mode of action of sodium, we compared the results with the molybdenum requirement in these organisms.

\section{METHODS}

Organisms and culture conditions. Anabaena torulosa was isolated in this laboratory by Fernandes \& Thomas (1982). Plectonema boryanum 594 was a gift from Dr R. Haselkorn, University of Chicago, Illinois, USA. Starter cultures were prepared using five-fold diluted cyanophycean medium, CM/5 (David \& Thomas, 1979) devoid of molybdenum and sodium and modified by adding either $3 \mathrm{mM}-\mathrm{NH}_{4} \mathrm{Cl}$ and $5 \mathrm{mM}$-HEPES, pH 7.0, for $A$. torulosa, 
or $10 \mathrm{~mm}-\mathrm{Ca}\left(\mathrm{NO}_{3}\right)_{2} \cdot 4 \mathrm{H}_{2} \mathrm{O}, \mathrm{pH} 7 \cdot 0$, for $P$. boryanum. The cyanobacteria were grown photoautotrophically at $25^{\circ} \mathrm{C}$ under continuous illumination $(5000 \mathrm{~lx})$ and aeration $\left(21 \mathrm{~min}^{-1}\right)$. Chlorophyll $a$ determinations were used to measure growth (Mackinney, 1941).

Induction and assay of nitrogenase. Cultures from the exponential growth phase in ammonium- or nitrate-supplemented media were harvested on Whatman GF/C fibre glass filters, aseptically washed and reinoculated into $\mathrm{CM} / 5$ medium free of combined nitrogen for induction of nitrogenase. $\mathrm{CM} / 5$ medium, which was suitably modified to avoid the inclusion of molybdenum or sodium or both, served as the basal medium for all the experiments. For $A$. torulosa nitrogenase was induced under aerobic conditions and for $P$. boryanum under microaerophilic conditions obtained by continuous sparging with argon. Nitrogenase activity was assayed as described previously (David et al., 1980) except that for P. boryanum all the operations including assays were done under an argon gas phase.

Measurement of molybdenum and sodium uptake. Uptake was examined by using the radiotracers ${ }^{99} \mathrm{Mo}$ and ${ }^{22} \mathrm{Na}$. Exponential phase cultures of $A$. torulos $a$ were harvested, washed and inoculated in $\mathrm{CM} / 5$ medium without molybdenum and sodium and were grown either in the presence or absence of ammonium for $24 \mathrm{~h}$. These molybdenum- and sodium-deficient cultures were harvested, resuspended in the fresh medium and used in uptake experiments. The assay mixture for sodium uptake contained $0.5 \mathrm{~mm}$-sodium and ${ }^{22} \mathrm{NaCl}$ to give $0.25 \mu \mathrm{Ci}$ $(9 \cdot 25 \mathrm{kBq}) \mathrm{ml}^{-1}$. Molybdenum uptake was measured in a mixture of [ ${ }^{99} \mathrm{Mo}$ ]ammonium molybdate $\left(4 \mu \mathrm{Ci} \mathrm{ml}{ }^{-1}\right)$ and $\mathrm{MoO}_{3}$ to give $50 \mu \mathrm{M}$ - molybdenum. The final volume of the assays was $2.5 \mathrm{ml}$. After the desired period of assay $2 \mathrm{ml}$ samples were filtered on Whatman GF/C fibre glass filters. Residues were washed three times with solutions of unlabelled $\mathrm{NaCl}$ or $\mathrm{MoO}_{3}$ (at equimolar concentrations to those of sodium and molybdenum in the assay mixture) and then three times with distilled water. The entire washing procedure took less than $1 \mathrm{~min}$. The filter papers were dried and counted in $10 \mathrm{ml} \mathrm{BBOT}(0.4 \%, \mathrm{w} / \mathrm{v})$ in a toluene/methanol mixture $(1: 1)$, using a Beckman LS-100 C liquid scintillation counter.

Preparation of cell-free extracts and SDS-PAGE. Cyanobacterial suspensions were concentrated to $50 \mu \mathrm{g}$ chlorophyll $a \mathrm{ml}^{-1}$, sonicated $\left(2 \mathrm{~min} \mathrm{ml} \mathrm{m}^{-1}\right)$ in a MSE-Soniprobe, and centrifuged at $1000 \mathrm{~g}$ for $10 \mathrm{~min}$. The supernatant was precipitated with cold $10 \%(\mathrm{w} / \mathrm{v})$ TCA and the pellet was washed twice with $70 \%(\mathrm{v} / \mathrm{v})$ ethanol and once with ether. After drying, the pellet was solubilized in $0.025 \mathrm{M}$-Tris $/ \mathrm{HCl}$ buffer, $\mathrm{pH} 8 \cdot 3$, containing $2 \%$ (w/v) SDS and $5 \%(\mathrm{w} / \mathrm{v}) \beta$-mercaptoethanol, by incubating in a boiling water bath for $5 \mathrm{~min}$. A 22 to $15 \%$ gradient slab gel was prepared with $25 \mathrm{ml}$ of each of the following two solutions: $14.55 \%(\mathrm{w} / \mathrm{v})$ acrylamide, $0.45 \%(\mathrm{w} / \mathrm{v})$ bis-acrylamide, and $0.8 \mathrm{mg}$ ammonium persulphate $\mathrm{ml}^{-1}$; and $21.34 \%$ acrylamide, $0.66 \%$ bis-acrylamide and $0.4 \mathrm{mg}$ ammonium persulphate $\mathrm{ml}^{-1}$. Both the solutions were prepared in $0.1 \mathrm{M}$-Tris $/ \mathrm{HCl}, \mathrm{pH} 8 \cdot 3$, containing $0.1 \%$ SDS. The running gel was overlayered with a stacking gel containing $2.5 \%$ acrylamide, $0.625 \%$ bis-acrylamide and $0.1 \%$ SDS in $0.1 \mathrm{M}-\mathrm{Tris} / \mathrm{HCl}, \mathrm{pH} \mathrm{6.8}$. The solubilized preparations were loaded on to the stacking gel and electrophoresed for $8 \mathrm{~h}$ at $20 \mathrm{~mA}$ with $0.025 \mathrm{M}$-Tris/glycine, $\mathrm{pH} 8.3$, containing $0.1 \% \mathrm{SDS}$ as a running buffer. Gels were fixed, stained with Coomassie Brilliant Blue $\mathrm{R}$ and photographed.

Chemicals, radioisotopes and gases. All the inorganic salts were from Sarabhai M. Chemicals, Baroda, India, or $\mathrm{BDH}$, except for $\mathrm{Ca}\left(\mathrm{NO}_{3}\right)_{2} .4 \mathrm{H}_{2} \mathrm{O}$ which was from Merck. ${ }^{22} \mathrm{NaCl}$ was from Amersham and $\left[{ }^{99} \mathrm{Mo}\right]$ ammonium molybdate from Isotope Division, Bhabha Atomic Research Centre, Trombay, India. Molecular weight standards for electrophoresis were obtained from Pharmacia. All the other chemicals were supplied by Sigma. Argon and acetylene gases were obtained from Indian Oxygen, Bombay, India, and standard ethylene from Matheson Gas Products, NJ, USA.

\section{RESULTS}

Anabaena torulosa showed complete dependence on sodium for growth under nitrogen-fixing conditions. After $5 \mathrm{~d}$ the chlorophyll $a$ content of the sodium-deficient and sodium-supplemented cultures was found to be $2 \cdot 1$ and $17.9 \mu \mathrm{g} \mathrm{ml}^{-1}$ respectively. Such a requirement was not seen when the medium was supplemented with combined nitrogen either in the form of nitrate or ammonium. The requirement was specific for sodium; it could not be replaced by other cations including $\mathrm{K}^{+}, \mathrm{Li}^{+}, \mathrm{Ca}^{2+}$ or $\mathrm{Mg}^{2+}$ (Table 1). All the sodium salts tested supported growth of the cyanobacterium irrespective of the accompanying anion. The requirement was very low since a sodium concentration above $22 \mu \mathrm{M}$ supported good growth of the cyanobacterium (Table 2). This value comprised approximately $15 \mu \mathrm{M}$-sodium detected as contaminant in sodium-deficient medium plus the added $8.0 \mu \mathrm{M}-\mathrm{NaCl}$.

The sodium requirement for growth, heterocyst differentiation and nitrogenase activity of $A$. torulosa was compared with its requirement for molybdenum - a known constituent of MoFe protein of nitrogenase. Response of the cyanobacterium to sodium starvation was very rapid but molybdenum-starved cultures could be obtained only after several passages in molybdenum-free 
Table 1. Specificity of sodium requirement for growth of nitrogen-fixing Anabaena torulosa

Various salts were added to sodium-deficient medium to increase the concentration of cation by $1.0 \mathrm{~mm}$. The initial chlorophyll $a$ content of the cultures at the time of inoculation was $3.43 \mu \mathrm{g} \mathrm{ml}^{-1}$ and the final chlorophyll $a$ content was determined $5 \mathrm{~d}$ after inoculation. No growth occurred when $\mathrm{KCl}, \mathrm{K}_{2} \mathrm{HPO}_{4}$, $\mathrm{LiOH}$ ( $\mathrm{pH}$ adjusted to 7.0 with $0.05 \mathrm{M}-\mathrm{HCl}$ ), $\mathrm{MgSO}_{4}$ or $\mathrm{CaCl}_{2}$ were added.

$\begin{array}{lc}\text { Salt added } & \begin{array}{c}\text { Growth } \\ \text { (increase in } \\ \text { chl. } a, \mu \mathrm{g} \mathrm{ml} l^{-1} \text { ) }\end{array} \\ \text { None } & 0 \cdot 0 \\ \mathrm{NaCl} & 14 \cdot 7 \\ \mathrm{Na}_{2} \mathrm{SO}_{4} & 12 \cdot 8 \\ \mathrm{Na}_{2} \mathrm{HPO}_{4} & 14 \cdot 5\end{array}$

Table 2. Effect of sodium on the growth of nitrogen-fixing Anabaena torulosa

The initial chlorophyll $a$ content of the cultures at the time of inoculation was $3.43 \mu \mathrm{g} \mathrm{ml}^{-1}$. Growth was measured, as the increase over this initial value, $5 \mathrm{~d}$ after inoculation. Sodium was added as $\mathrm{NaCl}$ and represents the concentration above background sodium contamination, which was $15 \mu \mathrm{M}$ (as determined in putatively sodium-free medium).

$\begin{array}{cc}\begin{array}{c}\text { Sodium concn } \\ (\mu \mathrm{M})\end{array} & \begin{array}{c}\text { Growth } \\ \text { (increase in } \\ \left.\text { chl. } a, \mu \mathrm{g} \mathrm{m} l^{-1}\right)\end{array} \\ 0 & 0 \cdot 0 \\ 5 & 0 \cdot 1 \\ 8 & 4 \cdot 6 \\ 10 & 8 \cdot 5 \\ 20 & 6.9 \\ 50 & 10 \cdot 6 \\ 100 & 11.7 \\ 250 & 14.8 \\ 500 & 15 \cdot 1 \\ 1000 & 15.4\end{array}$

Table 3. Effect of sodium and molybdenum on growth, heterocyst differentiation and nitrogenase activity of Anabaena torulosa

Basal medium was supplemented with $\mathrm{MoO}_{3}$ to give $50 \mu \mathrm{M}$-molybdenum or with $\mathrm{NaCl}$ to give $0.5 \mathrm{mM}$ sodium. Measurements were made $30 \mathrm{~h}$ after transfer to nitrogen-free media.

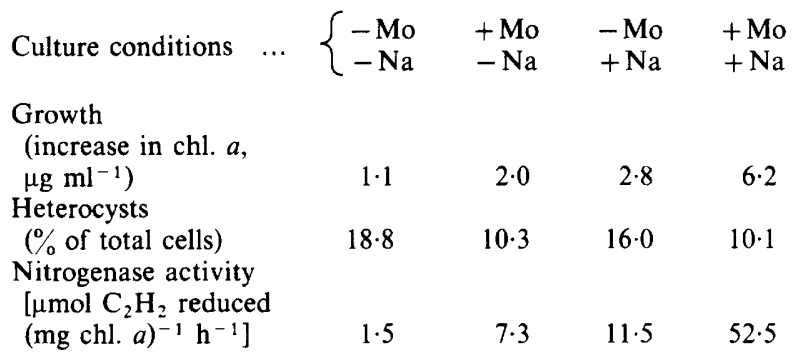

medium. Under both molybdenum and sodium deficiency, growth and nitrogenase activity were inhibited (Table 3). Sodium had no effect on heterocyst differentiation but molybdenum deficiency resulted in a higher percentage of heterocysts. Good growth and nitrogenase activity were observed only when both molybdenum and sodium were present (Table 3 ).

Addition of molybdenum or sodium to $A$. torulosa cultures starved of the respective cation enhanced nitrogenase activity (Fig. 1). A lag of $2 \mathrm{~h}$ (for sodium) and $4 \mathrm{~h}$ (for molybdenum) 


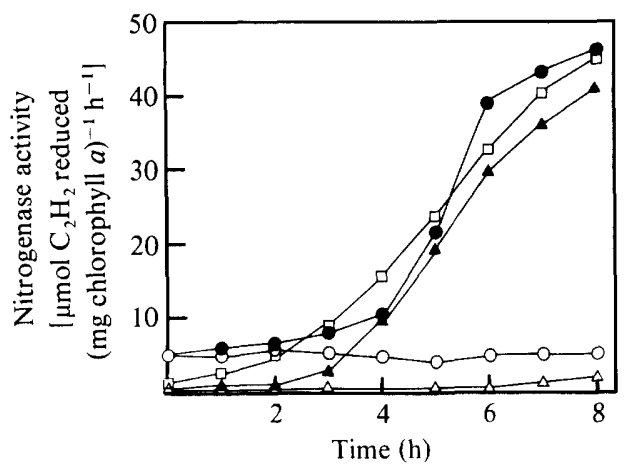

Fig. 1

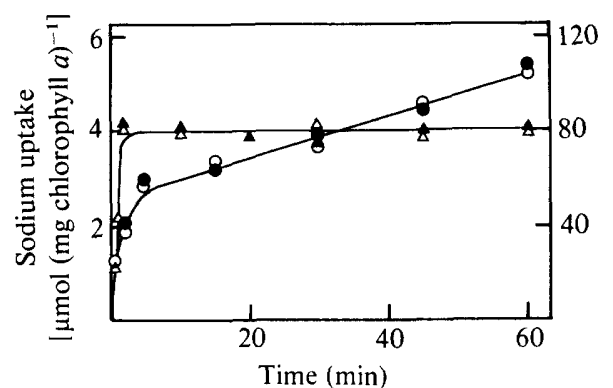

Fig. 2

Fig. 1. Requirement of molybdenum and sodium for nitrogenase activity of Anabaena torulosa, grown for $24 \mathrm{~h}$ under molybdenum deficiency $(O)$ or sodium deficiency $(\triangle)$. Cultures starved of the respective cation were supplemented at $0 \mathrm{~h}$ to give $50 \mu \mathrm{M}$-molybdenum $(\boldsymbol{O})$ or $0.5 \mathrm{~mm}$-sodium $(\boldsymbol{\Delta})$. A control culture $(\square)$ containing both molybdenum and sodium was included for comparison.

Fig. 2. Uptake of molybdenum and sodium by Anabaena torulosa. Uptake of molybdenum without $(O)$ or with $(\bullet) 0.5 \mathrm{~mm}$-sodium. Uptake of sodium without $(\triangle)$ or with $(\Delta) 50 \mu \mathrm{M}$-molybdenum. Details of the radioactive assays are given in Methods.

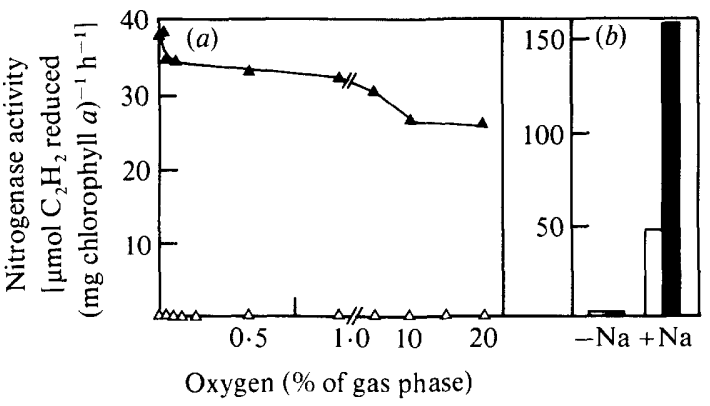

Fig. 3

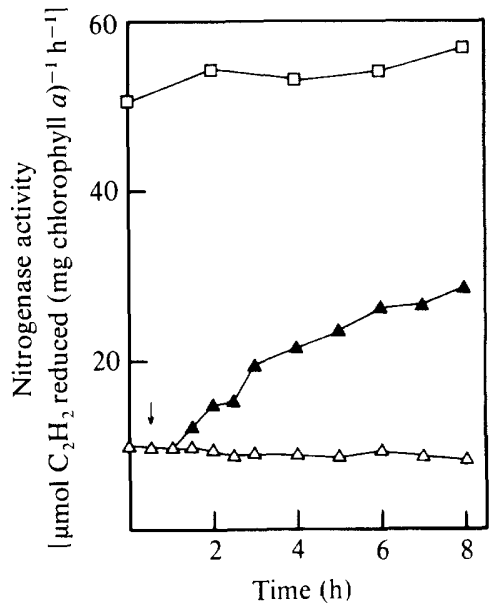

Fig. 4

Fig. 3. Effect of anaerobiosis on nitrogenase activity in Anabaena torulosa. (a) Aerobically grown cyanobacterial suspensions from sodium-deficient $(\Delta)$ and sodium-supplemented $(\boldsymbol{\Delta})$ cultures were assayed for acetylene reduction under an argon gas phase containing various concentrations $(\%$ gas phase, $v / v$ ) of oxygen. (b) Aerobically grown cultures were subjected to anaerobiosis by continuous sparging with argon for $90 \mathrm{~min}$, prior to assay, and then incubated for $30 \mathrm{~min}$ under $0.1 \mathrm{~atm}$ acetylene in argon. The open and closed bars show the nitrogenase activity of aerated and argon-sparged cultures respectively.

Fig. 4. Effect of sodium on nitrogenase activity in Plectonema boryanum 594. Nitrogenase was induced in nitrogen-free medium with $(\square)$ or without $(\Delta) 1 \mathrm{~mm}$-sodium under microaerophilic conditions. Sodium (1 mM) was added to sodium-deficient cultures $(\boldsymbol{A})$ at the time indicated by the arrow.

preceded such increased nitrogenase activity, which was fully restored by 5 to $6 \mathrm{~h}$ following addition of either cation. The duration of this lag could be reduced to $1 \mathrm{~h}$ for sodium and about $2 \mathrm{~h}$ for molybdenum if more dense cultures of $A$. torulosa ( $33 \mu \mathrm{g}$ chlorophyll $a \mathrm{ml}^{-1}$ ) were used.

The observed lag might have been due to a lag in the transport of the cations and it is possible that sodium regulated molybdenum transport. Accordingly the uptake of molybdenum and sodium by whole filaments of $A$. torulosa was examined. Sodium uptake was very rapid and 


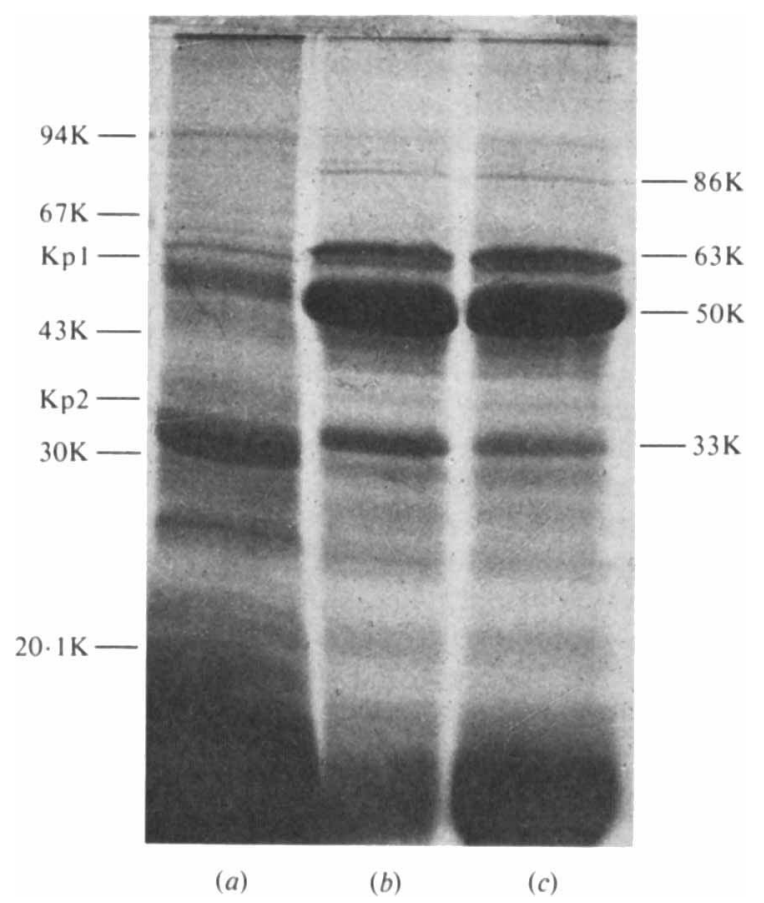

Fig. 5. Electrophoretic pattern of proteins from Plectonema boryanum 594. SDS extracts of proteins were electrophoresed on a 22 to $15 \%(w / v)$ polyacrylamide gradient slab gel with $0 \cdot 1 \%(w / v)$ SDS. The culture conditions were $(a) 10 \mathrm{mM}-\mathrm{Ca}\left(\mathrm{NO}_{3}\right)_{2}$, aerobic; $(b)$ nitrogen-free, sodium-deficient, argon; and (c) nitrogen-free, sodium-supplemented, argon. The in vivo specific activities of cultures $a, b$ and $c$ were $0,12$ and $59 \mu \mathrm{mol}$ acetylene reduced (mg chlorophyll $a)^{-1} h^{-1}$, respectively. The amount of protein loaded was $(a) 230 \mu \mathrm{g}$ and $(b)$ and $(c) 200 \mu \mathrm{g}$. The positions of bands belonging to molecular weight standards and $\mathrm{Kp} 1$ and $\mathrm{Kp} 2$ as visualized in the same slab gel (tracks not shown) are indicated on the left side. Bands marked on the right side show proteins synthesized under nitrogen-fixing conditions only, of which $63 \mathrm{~K}$ and $33 \mathrm{~K}$ bands have been previously identified as Plectonema nitrogenase proteins (see text).

saturated within minutes while molybdenum uptake continued slowly for at least $60 \mathrm{~min}$. Uptake of both the cations was independent of the presence or absence of the other cation (Fig. 2). Nitrogen-fixing $\boldsymbol{A}$. torulosa assimilated much more molybdenum than when grown in the presence of ammonium but, in the presence or absence of combined nitrogen, sodium did not affect molybdenum uptake, even at concentrations 50 times higher than those of molybdenum.

Preincubation under acetylene is known to activate nitrogenase both in vivo (David \& Fay, 1977) and in vitro (Thorneley \& Eady, 1977) and attempts were therefore made to see if sodium affected this property. In sodium-supplemented cultures of $A$. torulos $a$ this treatment resulted in a $2 \cdot 2$-fold enhancement of acetylene reduction while sodium-deficient cultures showed no such effect.

The possible role of sodium in protecting functional nitrogenase from oxygen inactivation was tested. This was done in A. torulosa in two ways (Fig. 3). Even the short-term anaerobiosis, maintained during the $30 \mathrm{~min}$ assay period, caused a $50 \%$ increase in nitrogenase activity of sodium-supplemented cultures (Fig. $3 a$ ). This indicates that even in heterocysts oxygen protection of nitrogenase does not seem to be perfect. When subjected to prolonged anaerobiosis by sparging for $90 \mathrm{~min}$ with argon prior to assay, sodium-supplemented cultures showed a 3.3fold increase in acetylene reduction (Fig. $3 b$ ). The enhancement was probably because of a further strengthening of protection of the enzyme due to oxygen exclusion, as well as stimulation of nitrogenase derepression due to nitrogen starvation. Significantly, in both the experiments nitrogenase activity in sodium-deficient cultures remained unaffected, indicating that sodium was not involved in mediating protection from oxygen. 
The filamentous, non-heterocystous cyanobacterium Plectonema boryanum also showed a requirement for sodium for nitrogenase activity (Fig. 4). Nitrogenase activity in sodiumsupplemented cultures was five times greater than that in sodium-deficient cultures. In the latter cultures addition of sodium enhanced nitrogenase activity. The lag preceding this enhancement was short $(30 \mathrm{~min})$ compared to that observed with the heterocystous $A$. torulosa $(2 \mathrm{~h})$ and was reduced to less than $30 \mathrm{~min}$ if higher density cultures $\left(35 \mu \mathrm{g}\right.$ chlorophyll $\left.a \mathrm{ml}^{-1}\right)$ were used.

The electrophoretic pattern of proteins from sodium-deficient and sodium-supplemented $P$. boryanum induced to synthesize nitrogenase is shown in Fig. 5. We found it convenient to use $P$. boryanum rather than $\boldsymbol{A}$. torulosa for these studies since the former had a much higher nitrogenase content than the latter. Cultures repressed for nitrogenase synthesis, by addition of nitrate to the medium and by aeration, were used as controls (Fig. 5a). Purified Klebsiella pneumoniae nitrogenase proteins (Kpl and $\mathrm{Kp} 2)$ were also electrophoresed for comparison. Four proteins having molecular weights near $86000(86 \mathrm{~K}), 63 \mathrm{~K}, 50 \mathrm{~K}$ and $33 \mathrm{~K}$ were found to be uniquely synthesized under nitrogen-fixing conditions, irrespective of the presence or absence of sodium (Fig. $5 b, c$ ). The protein bands at $63 \mathrm{~K}$ and $33 \mathrm{~K}$ are within the known range of molecular weights of nitrogenase proteins, which varies from $51 \mathrm{~K}$ to $61 \mathrm{~K}$ for MoFe protein and $30 \mathrm{~K}$ to $35 \mathrm{~K}$ for $\mathrm{Fe}$ protein in various diazotrophs (Yates, 1980). Similar bands were tentatively assigned earlier to the components of $P$. boryanum nitrogenase by Nagatani \& Haselkorn (1978).

\section{DISCUSSION}

A specific growth requirement for sodium has been shown for Anabaena cylindrica (Allen \& Arnon, 1955). We have now demonstrated that $A$. torulosa and Plectonema boryanum have a definite and specific requirement for sodium for nitrogenase activity and growth. The amount of sodium required is very low, with 20 to $25 \mu \mathrm{M}$ being the threshold level required by $A$. torulosa. Growth dependence on sodium is observed only in the absence of combined nitrogen, unlike $A$. cylindrica which has been found to require sodium for normal growth on nitrate (Brownell \& Nicholas, 1967). Sodium-deficient $A$. cylindrica showed enhanced nitrate reductase activity but did not grow, probably because of the resulting toxicity of excess nitrite which accumulated in the medium. With $A$. torulosa no such effects were seen and we have been able to maintain it in sodium-deficient media supplemented with nitrate or ammonium for over a year.

The response of $\boldsymbol{A}$. torulosa to sodium starvation is similar to that observed during molybdenum starvation, except that in the latter case heterocyst differentiation is markedly enhanced. Such a stimulation of heterocyst formation during molybdenum deficiency was earlier observed in A. cylindrica (Fay \& de Vasconcelos, 1974). This suggested that while the molybdenum-deficient cultures did not possess adequate amounts of the postulated nitrogenous inhibitor of heterocyst differentiation (Fogg, 1949; Wolk, 1967), it was present in the sodiumdeficient cultures in adequate quantities to regulate heterocyst formation. Since both molybdenum and sodium deficiency eventually resulted in nitrogen starvation due to lack of nitrogenase activity, it appears that nitrogen starvation may not be the sole cause of the absence of such inhibitor.

Nitrogenase activity in sodium- or molybdenum-deficient cultures of $A$. torulosa reappeared after a lag of 2 or $4 \mathrm{~h}$ following addition of sodium or molybdenum respectively. This lag, which could be reduced by using dense cultures, was not due to a corresponding lag in the transport of the cations. The kinetic difference in the rates of sodium and molybdenum transport possibly accounted for the difference in the duration of lag following their additions. The observed lag may perhaps be due to barrier(s) to the transport of the cations at the step of their entry into heterocysts. Significantly, in the non-heterocystous $P$. boryanum this lag was much shorter. Transport of molybdenum was independent of the presence of sodium, ruling out a possible symport or antiport of molybdenum with sodium, as has been observed for other cations (Dewar \& Barber, 1973), amino acids (Lanyi et al., 1976) and sugars (Stock \& Roseman, 1971) in bacteria. Clearly, the sodium requirement of nitrogenase is not related to the effect of sodium on molybdenum transport. 
Using anaerobically grown Anabaena variabilis, Rippka \& Stanier (1978) observed detectable nitrogenase activity only after $20 \mathrm{~h}$. A similar time lag was found in $A$. torulosa (Apte \& Thomas, 1980 ) while in anaerobically grown non-heterocystous $P$. boryanum induction of nitrogenase was observed after 8 to $9 \mathrm{~h}$ under our experimental conditions. Induction of nitrogenase in $5 \mathrm{~h}$ has been reported by Nagatani \& Haselkorn (1978) using high density cultures. In contrast, the enhancement of nitrogenase activity following addition of sodium or molybdenum to deficient cultures of cyanobacteria occured much faster. Subsequently the activity increased rapidly and was fully restored in $A$. torulosa. These observations favour involvement of molybdenum and sodium in the activation of enzyme pre-synthesized in their absence, rather than in its de novo synthesis. Indeed, $P$. boryanum induced to synthesize nitrogenase showed protein bands corresponding to components I and II of nitrogenase, in both the absence and presence of sodium. In this organism, as in $A$. cylindrica the molybdenum independence of nitrogenase synthesis has already been demonstrated (Nagatani \& Haselkorn, 1978; Hallenbeck \& Benemann, 1980). The close similarity in the requirement of molybdenum and sodium for nitrogenase activity in $A$. torulosa is suggestive of a complementary role for sodium in the enzyme activation. Thus the nitrogenase proteins are synthesized under sodium deficiency but remain catalytically inactive.

Subjecting sodium-deficient $A$. torulosa cultures to anaerobiosis did not promote nitrogenase activity in the absence of sodium and in the anaerobically induced $P$. boryanum also nitrogenase remained inactive under sodium deficiency. This eliminates the possibility that lack of protection from oxygen under sodium deficiency causes nitrogenase to be inactive.

The enhancement of acetylene reduction upon preincubation under acetylene in vivo (David \& Fay, 1977; David et al., 1978) has been shown to be due to conformational change(s) in the nitrogenase leading to an increase in its affinity towards acetylene (Apte et al., 1978). With purified nitrogenase preparations from Klebsiella pneumoniae (Thorneley \& Eady, 1977) such treatment resulted in increased electron flow through nitrogenase thereby enhancing its activities. However, the inactive nitrogenase of sodium-deficient cultures did not respond to preincubation under acetylene in vivo in our studies.

The nature of 'activation' of nitrogenase by sodium, whether due to direct effects on the enzyme molecule or to indirect effects, remains unresolved. Data provided in this paper indicate that cyanobacterial nitrogenase is synthesized in the absence of sodium, and that sodium is not involved in promoting nitrogenase activity indirectly by influencing molybdenum transport, protecting from oxygen or heterocyst differentiation. We have recently shown (Apte \& Thomas, 1983) that impairment of photosynthesis during sodium deficiency is caused by paucity of nitrogenous products due to the absence of a functional nitrogenase. It is possible that sodium may influence membrane potential, which in turn is known to regulate nitrogenase activity, at least in aerobic diazotrophs like Azotobacter (Haaker et al., 1980) and Anabaena variabilis (Hawkesford et al., 1981). Occurrence of a $\mathrm{Na}^{+} / \mathrm{H}^{+}$antiporter is known in cyanobacteria (Paschinger, 1977) and this may be involved in the maintenance of a requisite membrane potential conducive to nitrogenase activity.

We thank Dr R. R. Eady, ARC Unit of Nitrogen Fixation, Sussex, UK for providing us with purified nitrogenase proteins from Klebsiella pneumoniae.

\section{REFERENCES}

Allen, M. B. \& ARnon, D. I. (1955). Studies on nitrogen-fixing blue-green algae. II. The sodium requirement of Anabaena cylindrica. Physiologia plantarum 8, 653-660.

APTE, S. K. \& Thomas, J. (1980). Sodium is required for nitrogenase activity in cyanobacteria. Current Microbiology 3, 291-293.

APTE, S. K. \& Thomas, J. (1983). Impairment of photosynthesis by sodium deficiency and its relationship to nitrogen fixation in the cyanobacterium Anabaena torulosa. FEMS Microbiology Letters 16, 153-157.
Apte, S. K., David, K. A. V. \& Thomas, J. (1978). Conformational changes in the nitrogenase complex in vivo by preincubation under acetylene. Biochemical and Biophysical Research Communications 83, 1157 1163.

Batterton, J. C. \& Van BaAlen, C. (1971). Growth responses of blue-green algae to sodium chloride concentration. Achiv für Mikrobiologie 76, 151-165.

Brill, W. J., Steiner, A. L. \& ShaH, V. K. (1974). Effect of molybdenum starvation and tungsten on the synthesis of nitrogenase components in Klebsiella pneumoniae. Journal of Bacteriology 118, 986-989. 
Brownell, P. F. \& Nicholas, D. J. D. (1967). Some effects of sodium on nitrate assimilation and $\mathrm{N}_{2}$ fixation in Anabaena cylindrica. Plant Physiology 42,915921.

Cardenas, J. \& Mortenson, L. E. (1975). Role of molybdenum in dinitrogen fixation by Clostridium pasteurianum. Journal of Bacteriology 123, 978-984.

DAVID, K. A. V. \& FAY, P. (1977). Effects of long-term treatment with acetylene on nitrogen-fixing microorganisms. Applied and Environmental Microbiology 34, 640-646.

DAvid, K. A. V. \& Thomas, J. (1979). Extracellular polypeptides of Anabaena L-31: evidence for their role in regulation of heterocyst formation. Journal of Biosciences 1, 447-455.

David, K. A. V., Apte, S. K. \& Thomas, J. (1978). Stimulation of nitrogenase by acetylene: fresh synthesis or conformational change. Biochemical and Biophysical Research Communications 82, 39-45.

DAVID, K. A. V., APte, S. K., BanerJi, A. \& Thomas, J. (1980). Acetylene reduction assay for nitrogenase activity: gas chromatographic determination of ethylene per sample in less than one minute. Applied and Environmental Microbiology 39, 1078-1080.

Dewar, M. A. \& BARBER, J. (1973). Cation regulation in Anacystis nidulans. Planta 113, 143-155.

EADY, R. R. \& Postgate, J. R. (1974). Nitrogenase. Nature, London 249, 805-810.

Eady, R. R., Imam, S., Lowe, D. J., Miller, R. W., SMITH, B. E. \& Thorneley, R. N. F. (1980). The molecular enzymology of nitrogenase. In Nitrogen Fixation, pp. 19-35. Edited by W. D. P. Stewart \& J. R. Gallon. London: Academic Press.

FAY, P. \& DE VASConcelos, L. (1974). Nitrogen metabolism and ultrastructure in Anabaena cylindrica. II. The effect of molybdenum and vanadium. Archives of Microbiology 99, 221-230.

Fernandes, T. \& Thomas, J. (1982). Control of sporulation in the filamentous cyanobacterium Anabaena torulosa. Journal of Biosciences 4, 85-94.

FoGG, G. E. (1949). Growth and heterocyst production in Anabaena cylindrica Lemm. II. In relation to carbon and nitrogen metabolism. Annals of Botany 13, 241-259.

HaAker, H., LaAne, C. \& Veeger, C. (1980). Dinitrogen fixation and the proton-motive force. In Nitrogen Fixation, pp. 113-138. Edited by W. D. P. Stewart \& J. R. Gallon. London: Academic Press.

Hallenbeck, P. C. \& BenemanN, J. R. (1980). Effect of molybdenum starvation and tungsten on the synthesis and activity of nitrogenase in Anabaena cylindrica. In Nitrogen fixation (Enzymology, Physiology, Genetics): Applications in $\mathrm{H}_{2}$ and $\mathrm{NH}_{3}$ Production. Abstracts of a Société de Chimie Biologique/ Commission of the European Community Meeting on Nitrogen Fixation, Grenoble, June 1980. Edited by P. M. Vignais. Société de Chimie Biologique.

HaWkesford, M. J., ReED, R. H., Rowell, P. \& STEWART, W. D. P. (1981). Nitrogenase activity and membrane electrogenesis in the cyanobacterium Anabaena variabilis Kütz. European Journal of Biochemistry 115, 519-523.

KaHN, D., Hawkins, M. \& Eady, R. R. (1982). Nitrogen fixation in Klebsiella pneumoniae: nitro- genase levels and the effect of added molybdate on nitrogenase derepressed under molybdenum deprivation. Journal of General Microbiology 128, 779-787.

Kennedy, C. \& Postgate, J. R. (1977). Expression of Klebsiella pneumoniae nitrogen fixation genes in nitrate reductase mutants of Escherichia coli. Journal of General Microbiology 98, 551-557.

Kratz, W. A. \& MYers, J. (1955). Nutrition and growth of several blue-green algae. American Journal of Botany 42, 282-287.

Lanyi, J. K., Renthal, R. \& Macdonald, R. E. (1976). Light induced glutamate transport in Halobacterium halobium envelope vesicles. II. Evidence that the driving force is a light-dependent sodium gradient. Biochemistry 15, 1603-1610.

MaCKINNEY, G. (1941). Absorption of light by chlorophyll solutions. Journal of Biological Chemistry 140, 315-322.

NaGatani, H. H. \& BRILl, W. J. (1974). Nitrogenase. $\mathrm{V}$. The effect of Mo, W and $\mathrm{V}$ on the synthesis of nitrogenase components in Azotobacter vinelandii. Biochimica et biophysica acta 362, 160-166.

Nagatani, H. H. \& Haselkorn, R. (1978). Molybdenum independence of nitrogenase component synthesis in the non-heterocystous cyanobacterium Plectonema. Journal of Bacteriology 134, 597-605.

PASCHINGER, H. (1977). DCCD induced sodium uptake by Anacystis nidulans. Archives of Microbiology 113, 285-291.

RIPPKA, R. \& StANiER, R. Y. (1978). The effects of anaerobiosis on nitrogenase synthesis and heterocyst development by Nostocacean cyanobacteria. Journal of General Microbiology 105, 83-94.

SHAH, V. K. \& BRILL, W. J. (1977). Isolation of an ironmolybdenum cofactor from nitrogenase. Proceedings of the National Academy of Sciences of the United States of America 74, 3249-3253.

Stock, J. \& Roseman, S. (1971). A sodium dependent sugar co-transport system in bacteria. Biochemical and Biophysical Research Communications 44, 132138.

THORNELEY, R. N. F. \& EADY, R. R. (1977). Nitrogenase of Klebsiella pneumoniae. Distinction between proton-reducing and acetylene-reducing forms of the enzyme: effect of temperature and component protein ratio on substrate reduction kinetics. Biochemical Journal 167, 457-461.

ThoRneley, R. N. F., ChatT, J., EADY, R. R., Lowe, D. J., O'Donnell, M. J., Postgate, J. R., RichARDS, R. L. \& SMITH, B. E. (1980). The mechanism of biological nitrogen fixation: transient complexes in catalytic cycles. In Nitrogen Fixation, vol. I, pp. 171193. Edited by W. H. Orme-Johnson \& W. E. Newton. Baltimore: University Park Press.

Wolk, C. P. (1967). Physiological basis of the pattern of vegetative growth of a blue-green alga. Proceedings of the National Academy of Sciences of the United States of America 57, 1246-1251.

Wolk, C. P. (1973). Physiology and cytological chemistry of blue-green algae. Bacteriological Reviews 37, 32-101.

YATES, M. G. (1980). The biochemistry of nitrogen fixation. In The Biochemistry of Plants, vol. 5, pp. 164. London: Academic Press. 